Application of the British National Vegetation Classification to the Communities of the Park Grass Experiment through Time

Author(s): Mike E. Dodd, Jonathan Silvertown, Kevin McConway, Jacqueline Potts and Mick Crawley

Source: Folia Geobotanica \& Phytotaxonomica, Vol. 29, No. 3 (1994), pp. 321-334

Published by: Springer

Stable URL: http://www.jstor.org/stable/4181278

Accessed: 29-05-2015 13:06 UTC

Your use of the JSTOR archive indicates your acceptance of the Terms \& Conditions of Use, available at http://www.jstor.org/page/ info/about/policies/terms.jsp

JSTOR is a not-for-profit service that helps scholars, researchers, and students discover, use, and build upon a wide range of content in a trusted digital archive. We use information technology and tools to increase productivity and facilitate new forms of scholarship. For more information about JSTOR, please contact support@jstor.org. 


\title{
APPLICATION OF THE BRITISH NATIONAL VEGETATION CLASSIFICATION TO THE COMMUNITIES OF THE PARK GRASS EXPERIMENT THROUGH TIME
}

\author{
Mike E. Dodd ${ }^{1)}$, Jonathan Silvertown ${ }^{1)}$, Kevin McConway ${ }^{2)}$, Jacqueline Potts ${ }^{3)}$ \\ \& Mick Crawley ${ }^{4}$ \\ 1) Biology Department, The Open University, Walton Hall, Milton Keynes MK7 6AA, UK; \\ tel. +44908 652501, fax +44908 654167, E-mail M.E.DODD@OPEN.AC.UK \\ 2) Statistics Department, The Open University, Walton Hall, Milton Keynes MK7 6AA, UK \\ 3) Department of Statistics, Rothamsted Experimental Station, Harpenden, Herts AL5 2JQ, UK \\ 4) Dept. Pure \& Applied Biology, Imperial College, Silwood Park, Ascot, Berks SL5 7PY, UK
}

Keywords: Community stability, Computer aided vegetation classification, Grassland, Long-term experiment, MATCH, NVC

\begin{abstract}
The Park Grass Experiment at Rothamsted consists of a series of fertilizer treatments which have been applied to a species-rich hay meadow annually since 1856. Detailed botanical analyses of the plots between 1862 and 1992 were classified to one of the National Vegetation Classification (NVC) communities using the similarity measured by Czekanowski coefficient using computer program MATCH. Results indicated that "control" unfertilized plots were a relatively stable Cynosurus cristatus-Centaurea nigra dicotyledon-rich grassland. However mineral fertilized plots moved towards a species-rich Arrhenatherum elatius grassland MGle after 50-80 years and remained there. Plots receiving nitrogen fertilizer moved first to MGle then on to a Lolium perenne-Alopecurus pratensis grassland MG7D. Perhaps the most interesting plot was one which received a low rate of the soil acidifying ammonium sulphate fertilizer; the species composition changed towards a MG7D (Lolium perenne-Alopecurus pratensis) community between 1856 and 1903 but since then a liming treatment has been applied to part of the plot and the species composition on that part has recovered to a MG5 community resembling the control plots, taking 70-90 years to do so.
\end{abstract}

\section{INTRODUCTION}

The purpose of vegetation classification is to provide a means of recognizing similarities between spatially separated communities. The classification exercise is based on the assumptions (a) that variation in community composition is discontinuous in space, (b) that discontinuities in community composition reflect an underlying environmental heterogeneity, and (c) that there is reasonable temporal stability in community composition. Perhaps nowhere are spatial discontinuities in community composition more obvious than in the Park Grass Experiment (PGE) at Rothamsted, England, where species-rich meadow plant communities are divided from species-poor ones of various types by boundaries that are unmistakable to

Vol. 29, No. 1 (pages 1-112) of the Folia Geobotanica et Phytotaxonomica was issued 1st June 1994
Vol. 29, No. 2 (pages 113-320) of the Folia Geobotanica et Phytotaxonomica was issued 8th August 1994 
the naked eye. These community boundaries demarcate a series of grassland plots that have received different fertilizer and liming treatments for up to 139 years. The PGE is a textbook example of the correspondence between edaphic conditions and grassland community composition (BRENCHLEY \& WARINGTON 1958, ThURSTON 1969, Williams 1978). Indeed PIGOTT (1982) stated that the simple fertilizer treatments converted one type of vegetation into another and suggested that many of these vegetation types could be matched closely to vegetation occurring naturally in lowland England.

In this paper we explore the temporal aspect of community composition in the PGE by using the British National Vegetation Classification (NVC; RoDwELL 1991, 1992a, 1992b) to track the composition of communities as it has changed over more than a century. We ask whether unfertilized (control) plots in the PGE have had a stable classification through time, how quickly plots fertilized in a variety of ways lost or changed their original classification, and how quickly communities that had been severely altered by fertilizer recovered when treatments were stopped or ameliorated.

\section{METHODS}

The Park Grass Experiment was started in 1856 on an area which had been a meadow for several hundreds of years. The site was originally selected as being level and having uniform herbage. The traditional management was to remove one hay crop and graze the aftermath with sheep. The land was occasionally manured with farmyard manure (FYM), but there was no manure for the three seasons preceding the commencement of the experiment (LAWES \& GILBERT 1858) and sheep grazing ceased in 1875 , to be replaced by a second hay 'cut.

A range of organic and inorganic fertilizer treatments have been applied to plots every year; the details are given by WILLIAMS (1978) and are summarised in Fig 1. Treatments with sufficient data to be discussed here could be divided into those receiving inorganic nutrients but no nitrogen (plots $7,8,15$ ), those receiving nitrogen in the form of ammonium sulphate which progressively acidified the soil (JOHNSTON et al.; plots $1,9,10,11 / 1,11 / 2$ ), those receiving nitrate (plots 14,17), and one receiving farmyard manure (plot 19). There are now effectively three "controls"; plots 3 and 12 which have received no additional fertilizers since the experiment started, and plot 2 which received FYM 1856-1862 but no fertilizer since. Most of the plots were split in 1903 or 1920; one half continued to receive the fertilizer treatment as before; the other half received the fertilizer plus a liming treatment. The liming treatment was modified in 1965 (WILLIAMS 1978). Liming treatments neutralised the acidifying effect of the ammonium fertilizers.

Botanical composition of the plots has been recorded at irregular intervals. The samples taken between 1862 and 1976 consisted of detailed examination of a random sample of cut hay, dividing it into the percentage dry weight of each species present. The plot areas cut for hay were at least $36 \mathrm{~m}^{-2}$. In 1991 and 1992 six replicate $0.25 \mathrm{~m} \times 0.5 \mathrm{~m}$ quadrats per treatment were cut before the hay and again divided into the percentage dry weight of each species present. These quadrats were amalgamated in subsequent analysis because individually they were too small to be a representative sample of the grassland community. The number of species recorded from the random sample of hay and the amalgamated quadrat samples were similar and generally within the year to year variability of hay samples previously recorded. Effectively therefore we had data for only one sample per treatment per year whereas ideally, 




Fig. 1. Plot plan of the Park Grass experiment showing the treatments discussed in this paper and plot areas as they existed between 1903 and 1964 (the period when most of the data analysed here were collected). Hatched out plots contained too few or unsuitable data for this analysis. 
Table 1 . The percentage dry weight of each species converted into Domin scores

\begin{tabular}{cc} 
Percentage & Domin \\
\hline $90.01-100.00$ & 10 \\
$75.01-90.00$ & 9 \\
$50.01-75.00$ & 8 \\
$33.01-50.00$ & 7 \\
$25.01-33.00$ & 6 \\
$10.01-25.00$ & 5 \\
$4.01-10.00$ & 4 \\
$1.00-4.00$ & 3 \\
$0.51-1.00$ & 2 \\
$0.01-0.50$ & 1 \\
\hline
\end{tabular}

for comparison with the tables in the NVC, several are needed so that constancy of species between samples can be calculated.

An objective method of classifying the historical samples was needed so the MATCH computer program (Unit of Vegetation Sciences, University of Lancaster) was used to match the plant communities found in the plots to the plant communities as defined by the National Vegetation Classification. MATCH has been used as a monitoring tool since 1990 to assess the changes in calcicolous grassland ( $\mathrm{RICH}$ et al. 1993), although the development team recognise that it is simply a crude guide to the identification of vegetation types (RODWELL pers com.). The MATCH program works by comparing the constancy values of each species in the sample data with the constancy profile of the communities recognised in "British Plant

Communities". Using the Czekanowski similarity coefficient the community to be identified is classified into the vegetation type giving the highest similarity value. For the program to work effectively several samples have to be supplied so that the between sample constancy of each species can be calculated. Constancy values range between I for rarely occurring species $(0-20 \%$ of the samples) to $V$ for species which occur in $80-100 \%$ samples (KERSHAW 1973). If only one sample is supplied then each species present has a maximum constancy value of $\mathrm{V}$. The amount (Domin score) of each species in each sample does not affect the constancy value. However in the final table comparing test data with the NVC community, the Domin scores (Tab. 1) are used to note any substantial discrepancies between the amount of each species found in the test data and the amount found in the NVC community.

The program needed several samples to work effectively but there was only one sample per plot/year available. Therefore as well as looking at the data for single samples per plot year several samples from the same plot over a range of years during which there were no major changes in species composition were put together using years as replicates. The exact groupings of years and number of groups were largely determined by data availability since there are substantial gaps in the botanical record at Park Grass.

The four periods (A - D) chosen for analysis were:

A: $1867-1877$, a time of gradual change during the early part of the experiment, when most plots were sampled in 1867,1872 and 1877 . A sample in 1862 was not used as the fertilized plots were still changing rapidly at that time.

B: 1900-1929, and C: 1930-1949, periods of relative stability, with frequent sampling of several plots during the 1920's and 1930's.

D: 1973-1992, there were only three samples on most plots, samples occurred in 1991, 1992 and one in the mid 1970's.

Only those plots for which there were the most data were selected for analysis. These covered a full range of fertilizer treatments and "controls". Data from both single year samples 
Table 2. Overview of the most frequent NVC vegetation types used in Tab. 3.

\section{MG1}

Arrhenatherum elatius grassland Arrhenatheretum elatioris BR.-BL. 1919. Constant species Arrhenatherum elatius and Dactylis glomerata. The community is generally a tussocky ungrazed grassland occurring on road verges, neglected agricultural land and badly managed pastures.

\section{MGle}

Centaurea nigra sub-community of Arrhenatherum elatius grassland. Richer and more varied than the other Arrhenathera sub-communities. The preferential species for this sub-community are Trisetum flavescens and Avenula pubescens. The tall dicotyledons Heracleum sphondylium and Centaurea nigra are also often present.

\section{MG3}

Anthoxanthum odoratum-Geranium sylvaticum grassland. Constant species Agrostis capillaris, Alchemilla glabra, Anthoxanthum odoratum, Cerastium fontanum, Conopodium majus, Dactylis glomerata, Festuca rubra, Geranium sylvaticum, Holcus lanatus, Plantago lanceolata, Poa trivialis, Ranunculus acris, Rumex acetosa, Sanguisorba officinalis, Trifolium repens. This is an upland community of tall grasses and herbaceous dicotyledons which is confined to areas of traditional hay management.

\section{MG5}

Cynosurus cristatus-Centaurea nigra grassland Centaureo-Cynosuretum cristati BR.-BL. et TX. 1952. Constant species Agrostis capillaris, Anthoxanthum odoratum, Centaurea nigra, Cynosurus cristatus, Dactylis glomerata, Festuca rubra, Holcus lanatus, Lotus corniculatus, Plantago lanceolata, Trifolium pratense and T. repens. A dicotyledon-rich grassland typical of traditional grazed hay-meadows of lowland Britain.

MG5a

Lathyrus pratensis sub-community: Centaureo-Cynosuretum typicum BR.-BL. et TX. 1952. Legumes are particularly prominent and grass growth may be poor. Lathyrus pratensis and Lolium perenne preferentials.

\section{MG5b}

Galium verum sub-community: Centaureo-Cynosuretum, Sub-Association of Thymus drucei BR.-BL. et TX. 1952. Generally a short close sward with a wide variety of grasses including Trisetum flavescens and Avenula pubescens although the dicotyledons are usually more prominent especially Galium verum which can give the sward a yellow appearance in summer.

\section{MG6}

Lolium perenne-Cynosurus cristatus grassland Lolio-Cynosuretum cristatii (BR.-BL. et DE LEEUW 1936) TX. 1937. Constant species Cerastium fontanum, Cynosurus cristatus, Festuca rubra, Holcus lanatus, Lolium perenne and Trifolium repens. Short, grass dominated, pastures and amenity swards widespread in many parts of Britain.

\section{MG6b}

Anthoxanthum odoratum sub-community of Lolium perenne-Cynosurus cristatus grassland. The distinctive preferential grass in this richer sub-community is Anthoxanthum odoratum. There are also occasional hay-meadow species such as Centaurea nigra, Leucanthemum vulgare and Leontodon hispidus.

\section{MG7D}

Lolium perenne-Alopecurus pratensis grassland. A tall species-poor sward often treated as a hay meadow. It contains Lolium perenne and Alopecurus pratensis co-dominant and smaller amounts of Dactylis glomerata. Occasional species include Holcus lanatus, Agrostis capillaris, A. stolonifera, Anthoxanthum odoratum and the dicotyledons Taraxacum officinale agg., Ranunculus repens, Cerastium fontanum, Rumex acetosa and Trifolium pratense. The community most frequently occurs on moist fertile soils of lowland river valleys.

MG9

Holcus lanatus-Deschampsia cespitosa grassland. Constant species include Deschampsia cespitosa ssp. cespitosa and Holcus lanatus. A coarse tussocky sward of permanently moist gleyed soils throughout the British lowlands. 


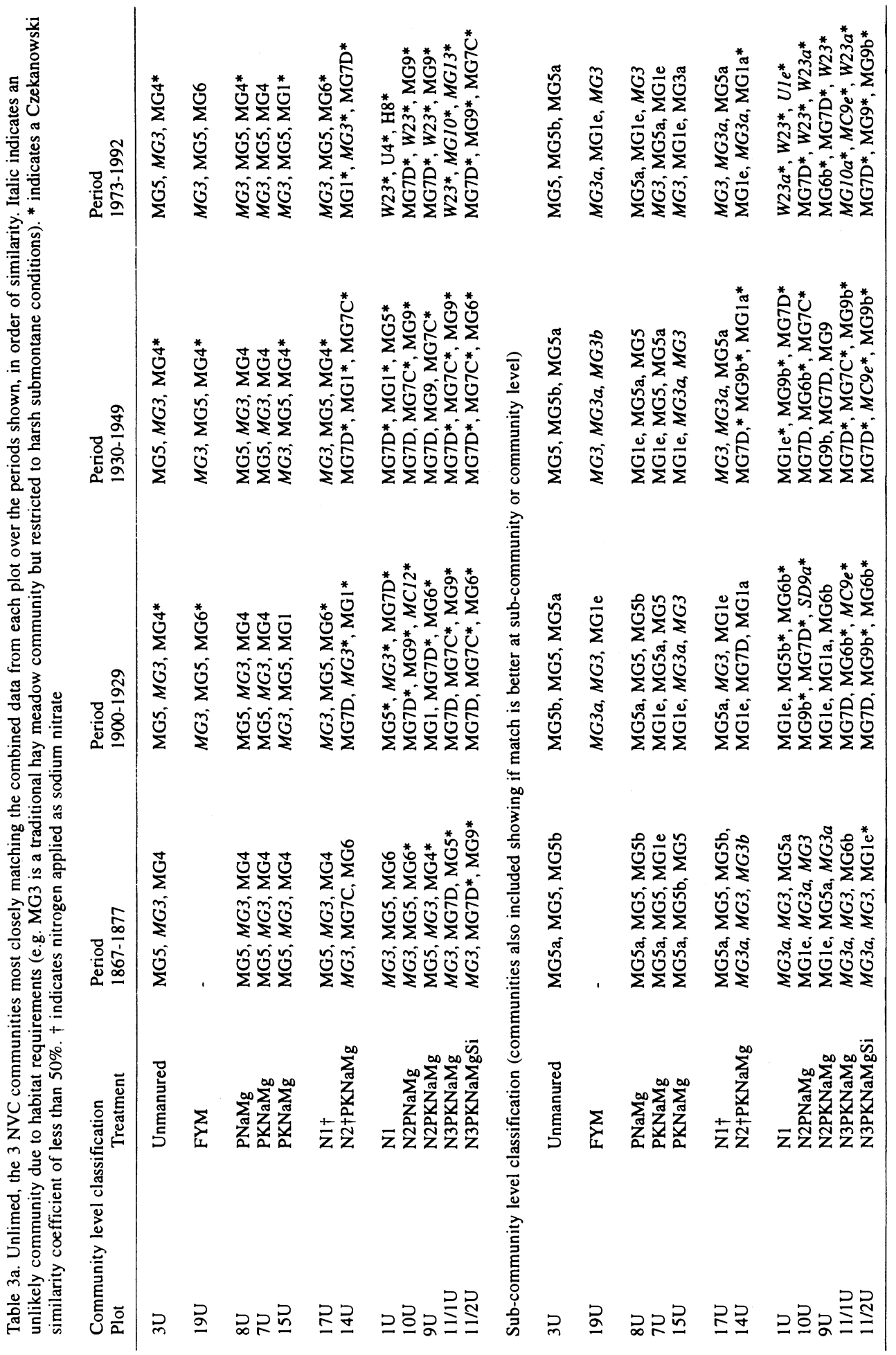




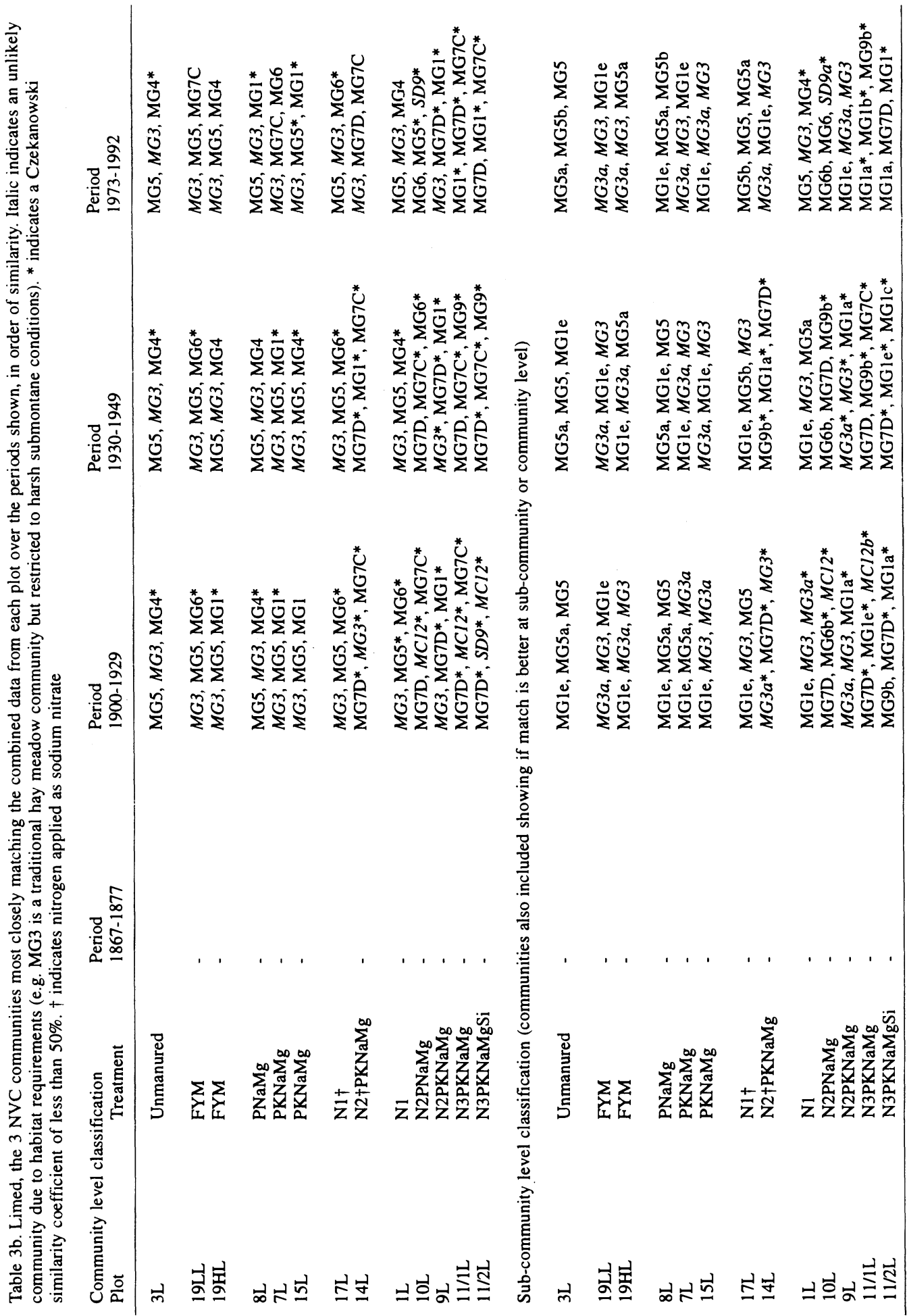




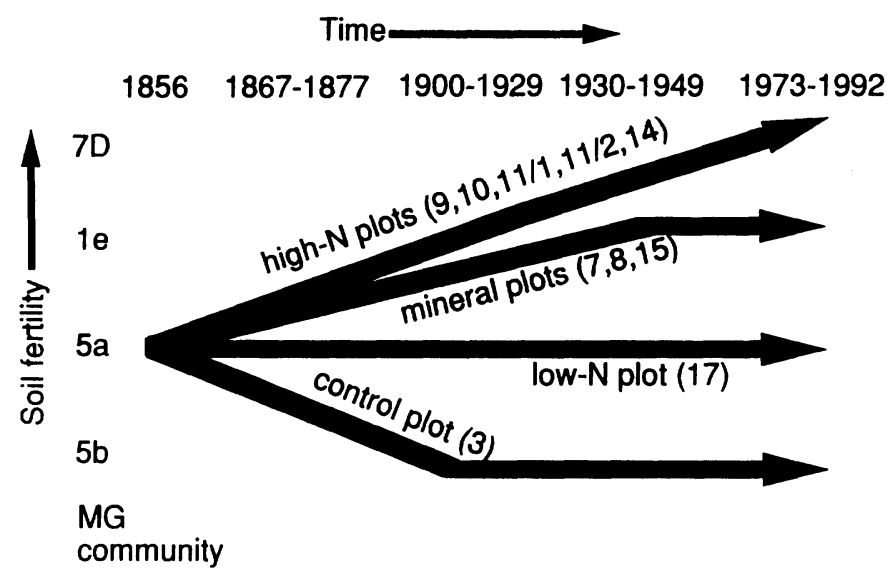

Fig. 2. Changes in NVC grassland community through time in relation to fertilizer treatment.

and tables from combined year samples where there were enough data were assigned to NVC types (a) using the MATCH computer program and (b) using the key to mesotrophic grassland in RoDWELL (1992b). Both must be used critically, particularly where, as here the data were not collected in the standard way.

Communities of the NVC are designated by a two letter code followed by a number; for example MG5 indicates mesotrophic grassland group 5. Sub-communities are indicated by a lower case letter following the main code for example MG5a is the Lathyrus pratensis sub-community of an MG5 grassland. However the system has one exception: the highly improved agricultural communities MG7A, MG7B, MG7C, MG7D, MG7E and MG7F; they have no sub-communities and there is no overall community MG7.

\section{RESULTS}

\section{Unlimed plots}

The control (unfertilized) plots 2, 3 and 12 matched to community MG5 for almost all individual years. Plot 3 gave a MG5 for each of the groups of years (Tab. 3a, b; plots 2 and 12 contained insufficient data to appear in the table). Sub-communities for the control plots varied between MG5, MG5a and MG5b.

Plots receiving mineral fertilizers but no nitrogen $(7,8$ and 15) were more variable than the controls but still gave MG5 or MG3 as the main community each year. The sub-community level classifications were more variable, often giving MGle for individual years or for groups of years between 1900 and 1949, for the latest period 1973-1992 the community matched to either a MG5 or MG1e.

Plot 17, which received a small amount of sodium nitrate, gave similar results to the controls generally producing a MG5 or MG3.

The other plots receiving nitrogen, especially in the form of ammonium sulphate, were much more variable with individual years giving best matches to communities from either mesotrophic grassland, sand dunes, mires, upland, or woodland. Generally the plots moved 
to a MG7D or MG1e community between 1900 and 1949. In the most recent surveys some of the plots matched to the scrub community W23.

\section{Limed plots}

Liming had little effect on the communities achieved by the fertilizer treatments when compared to the unlimed parts of the same plots. There was however one notable exception, plot 1 (ammonium sulphate, lowest dosage) limed, which instead of moving towards a MG7D or W23, returned to MG5.

The matching procedure gave a number of NVC communities which were unlikely to occur in the habitat conditions at Park Grass, including MG3 - a montane hay meadow; several periodically flooded grassland types such as MG10, MG13; the maritime and sand dune communities MC9, MC12, SD9; the acid heath type communities U1, U4, and H8; and the scrub community W23. Of these only MG3 gave a similarity coefficient of greater than $50 \%$ for any plot/year groups (Tab. 2).

The key to mesotrophic grassland (RODWELL 1992b) often gave the same plant community as MATCH but it did not give any MG3 results. MG3 was excluded in the dichotomous key as none of the plots had frequent Geranium sylvaticum, Alchemilla glabra or Alchemilla xanthochlora. The control plots gave a MG5; the mineral fertilized plots gave MG1e, MG4 or MG5. The non acidified nitrogen plots suggested a MG1 but none of the sub-communities were suitable. The acidified plots often did not fit in to any of the grassland types in the key.

Trends are summarised in Fig 2.

\section{DISCUSSION}

\section{Have control plots had a stable classification?}

It is clear that the "controls" have remained as Cynosurus cristatus - Centaurea nigra dicotyledon-rich grassland [Mesotrophic Grassland 5 in the NVC (Tab. 2)] throughout the 130 years of the experiment; indeed Rodwell (1992b) used Park Grass plot 3 as an example of MG5b. The question as to whether plot 3 is stable in terms of sub-communities is less easy since in Tab. 2, in any one period, the similarity coefficients for diagnosis MG5a, MG5 or MG5b were separated by a maximum of just $3.5 \%$. In the earliest period (1867-1877) the most likely match was to the Lathyrus pratensis sub-community MG5a. The plot was in the process of slow decline in yield after the cessation of traditional management and one of the main preferentials for the MG5b sub-community, Galium verum, was not yet present. In later periods this species was recorded and the sub-community moved to a MG5 or MG5b.

\section{How quickly have fertilized plots changed their classification?}

It is interesting that plots receiving mineral nutrients alone also match to an MG5 community throughout even though RODWELL (1992b) used BRENCHLEY \& WARINGTON's (1958) description of plots 7 and 8 as an example of the Centaurea nigra sub-community of Arrhenatherum elatius grassland (MG1e). The main differences between the unlimed part of plot 3 and the mineral fertilized plots 7 and 8 are species such as Heracleum sphondylium and Filipendula ulmaria which grow on plots 7 and 8 but not on plot 3, and Cynosurus cristatus and Sanguisorba minor which occur on plot 3 but not on the unlimed parts of plots 
7 and 8. Sward height on plots 7 and 8 may be twice that of the unfertilized plots and can contain large amounts of Lathyrus pratensis especially on the limed parts of plot 7 . The extensive sprawling nature of Lathyrus plants could have seriously influenced the results if small fixed quadrats had been used in the sampling method. However the general proceedure at Park Grass was to take random samples from large areas of cut hay located in a different part of the plot each year. Thus the location of samples was similar to that suggested in the NVC and the use of years as replicates evened out some of the temporal variability of individual species. Indeed the botanical composition of the hay samples themselves were considerably more stable year to year than visual surveys of the same plots 1920-1979 (DoDD unpubl.). Visual surveys occasionally "missed" common species but they also sometimes found very rare species and were generally less reliable than the hay samples.

The sub-communities on the mineral fertilized plots again matched to a MG5a for the first period but then moved to MGle. Sub-community MGle is the most species-rich and varied of the generally coarse-leaved, tussocky Arrhenatherum grasslands (Tab. 2). In fact this sub-community can be dominated by a range of grasses such as Dactylis glomerata and Holcus lanatus in addition to Arrhenatherum elatius.

Plot 17 , which receives just $40 \mathrm{~kg} \mathrm{~N} \mathrm{ha}^{-1}$, and plot 19, which receives FYM every fourth year, also match to a MG5 community. Both plots therefore receive some nitrogen fertilizer but not enough for a major shift away from MG5, although the sub-communities on plot 19 suggest a MGle. In fact the plots usually considered as "controls" receive no inorganic or organic fertilizer applications whereas traditional hay meadow management normally involves winter grazing and the light application of farmyard manure. It is not clear whether the fertilizer regime of traditional management plus the increasing levels of atmospheric deposition (20 kg N ha ${ }^{-1}$ year $^{-1}$ at present, GouLdING \& PoulTON 1985) would be expected to maintain a MG5 at Park Grass or move controls towards a MG1e.

Treatments giving a higher level of nitrogen ( 96 or $144 \mathrm{~kg} \mathrm{~N} \mathrm{ha}^{-1}$ ) plus other nutrients usually moved the community to a tall, rather species-poor Lolium perenne - Alopecurus pratensis grassland (MG7D) within the first (1867-1877) or at least by the second (1900-1929) period of assessment. There was some evidence that the plots receiving $96 \mathrm{~kg} \mathrm{~N} \mathrm{ha}^{-1}$ moved to MGle during the first 40 years and then on to MG7D (Tab. 3). There is also a suggestion that the acidified plots are now moving away from MG7D towards the herbaceous element of the acidic scrub community W23. However these acid plots are very species-poor often only containing between one and four species and this makes diagnosis of any community rather doubtful.

The MG7D community is most characteristic of moist and fertile alluvial soils (Tab. 2) (RODWELL 1992b). However, the similarity coefficients for the matches to this community were often less than $50 \%$ indicating a poor match. One explanation is that Lolium perenne, one of the co-dominant species in MG7D, is generally rather rare at Park Grass. It is not clear why Lolium is so uncommon, but one possibility is that during the early part of the experiment Lolium became extinct on the acidified plots and was then unable to reinvade once the liming treatments started. However this does not explain why Lolium also declined and disappeared between 1877 and 1903 on the plots fertilized with the non-acidifying sodium nitrate. ThuRSTON, WiLliams \& JOHNSTON (1976) suggested that the genotype of Lolium present at Park Grass developed under grazing and was therefore not well adapted to a hay regime. The low persistence of Lolium perenne in many pasture situations unless "well managed" is well 
known and THOMPSON \& GRIME (1983) and ROBERTS (1986) suggest that it relates to the transient nature of the seed bank and to the ineffective vegetative spread.

One community diagnosis that might have been expected from these nitrogen fertilized plots was MG6. RODWELL (1992b) states that many stands of traditionally managed meadow vegetation which have been "improved" by the application of artificial fertilizers are now grouped with the Lolium perenne - Cynosurus cristatus grassland MG6. However species of high constancy in MG6, Lolium perenne, Cynosurus cristatus, Trifolium repens, Cerastium fontanum and Festuca rubra are generally not present in the nitrogen fertilized plots at Park Grass. One plot which did indicate a MG6 was plot 10 but this was only after 70 years of liming to neutralise the acidifying effect of ammonium sulphate fertilizer.

\section{How quickly have fertilized plots recovered?}

The only plot to recover the original MG5 plant community after a substantial perturbation caused by fertilizer treatment was plot 1 limed. This plot received the lowest level of solely nitrogen fertilizer $\left(40 \mathrm{~kg} \mathrm{~N} \mathrm{ha}^{-1}\right)$ as ammonium sulphate. Soil on the unlimed part of plot showed some degree of acidification in the early years and by 1923 it had achieved $\mathrm{pH} 4.8$ compared to $\mathrm{pH} 5.7$ in 1856; by 1984 the $\mathrm{pH}$ had declined further to $\mathrm{pH} 3.7$ indicating considerable acidification (JOHNSTON et al. 1986). MATCH had difficulty classifying communities on the unlimed part of the plot since for the two most recent periods (1930-1949, 1973-1992) it has been completely dominated by either Festuca rubra, Agrostis capillaris or Anthoxanthum odoratum. The grassland is short and tussocky with a few gaps and somewhat resembles the Breckland grass heath vegetation of East Anglia. Parts of plot 1 which received lime to neutralise ammonium sulphate never achieved these very low $\mathrm{pH}$ values or the extremes of botanical composition.

It is clear that the limed part of the plot did not follow the same course of community degeneration as the unlimed part but to decide if it "recovered" we need to compare the plot in 1903, when the liming started, with later community measurements. There was no botanical survey of plot 1 in 1903. The two closest surveys on either side of 1903 were in 1877 and 1914: these gave a community of MG6 or MG7D. An alternative way of assessing the community at the start of liming is to examine plot 1 unlimed for the period 1900-1929 (Tab. 3); none of the similarity coefficients are particularly high although the most likely community is MG5 with a coefficient of $44.7 \%$, slightly better than MG7D diagnosis with a coefficient of $42.7 \%$. In Table 4 some of the most important missing species, from the unlimed part of plot 1 for the period 1900-1929, are the legumes Lotus corniculatus, Trifolium repens, Trifolium pratense and Lathyrus pratensis. These species return to the limed part of the plot in the order Lathyrus pratensis and Lotus corniculatus, Trifolium pratense, Trifolium repens and by the 1973-1992 sample period all four species are present. The species composition on plot 1 limed and the other MG5 plots are now very similar, the only notable difference being the lack of Cynosurus cristatus on plot 1 limed.

It is difficult to be precise about the time scale of recovery given the large gaps between some of the botanical surveys and inexact nature of plant communities. However an approximate figure for the recovery of a MG5 from an "improved" pasture would be 70-90 years. 
Table 4. Species composition on the unlimed part of plot 1 during the period 1900-1929(B), also on the limed part of plot 1 during the periods 1900-1929(B), 1930-1949(C), 1973-1992(D), matched against a NVC community diagnosis of MG5. Czekanowski similarity coefficients $1 \mathrm{U}(\mathrm{B})=44.7,1 \mathrm{~L}(\mathrm{~B})=46.5,1 \mathrm{~L}(\mathrm{C})=54.2,1 \mathrm{~L}(\mathrm{D})=$ 56.9.

\begin{tabular}{|c|c|c|c|c|c|c|c|c|c|c|}
\hline & \multicolumn{5}{|c|}{ Constancy values } & \multicolumn{5}{|c|}{ Maximum Domin score } \\
\hline & 1UB & 1LB & 1LC & 1LD & MG5 & $1 \mathrm{UB}$ & $1 \mathrm{LB}$ & $1 \mathrm{LC}$ & 1LD & MG5 \\
\hline Festuca rubra & V & V & V & V & $(\mathrm{V})$ & 6 & 6 & 5 & 4 & (8) \\
\hline Cynosurus cristatus & . & . & . & . & (V) & 0 & 0 & 0 & 0 & (8) \\
\hline Lotus corniculatus & . & V & V & V & (V) & 0 & 1 & 3 & 2 & (7) \\
\hline Plantago lanceolata & . & . & V & V & (V) & 0 & 0 & 5 & 7 & (7) \\
\hline Holcus lanatus & V & V & V & V & (IV) & 5 & 4 & 4 & 3 & (6) \\
\hline Dactylis glomerata & V & V & V & V & (IV) & 5 & 5 & 5 & 7 & (7) \\
\hline Trifolium repens & . & . & . & V & (IV) & 0 & 0 & 0 & 1 & (9) \\
\hline Centaurea nigra & V & $\mathbf{V}$ & V & V & (IV) & 5 & 5 & 4 & 3 & (5) \\
\hline Agrostis capillaris & V & V & V & V & (IV) & 5 & 5 & 3 & 5 & (8) \\
\hline Anthoxanthum odoratum & V & V & V & V & (IV) & 5 & 4 & 4 & 3 & (8) \\
\hline Trifolium pratense & . & . & V & $\mathrm{V}$ & (IV) & 0 & 0 & 2 & 1 & (5) \\
\hline Lolium perenne & . & . & . & . & (III) & 0 & 0 & 0 & 0 & (8) \\
\hline Bellis perennis & . & . & . & . & (II) & 0 & 0 & 0 & 0 & (7) \\
\hline Lathyrus pratensis & . & V & V & $\mathrm{V}$ & (II) & 0 & 2 & 3 & 1 & (5) \\
\hline Leucanthemum vulgare & . & . & . & . & (II) & 0 & 0 & 0 & 0 & (3) \\
\hline Festuca pratensis & . & . & . & III & (I) & 0 & 0 & 0 & 3 & (5) \\
\hline Knautia arvensis & . & . & IV & . & (I) & 0 & 0 & 3 & 0 & (4) \\
\hline Juncus inflexus & . & . & . & . & (I) & 0 & 0 & 0 & 0 & (5) \\
\hline Galium verum & III & . & . & . & (II) & 1 & 0 & 0 & 0 & (6) \\
\hline Trisetum flavescens & III & V & V & III & (III) & 1 & 2 & 3 & 3 & (6) \\
\hline Achillea millefolium & V & V & V & V & (III) & 1 & 3 & 3 & 4 & (6) \\
\hline Carex flacca & . & . & . & . & (I) & 0 & 0 & 0 & 0 & (4) \\
\hline Sanguisorba minor & . & . & . & V & (I) & 0 & 0 & 0 & 1 & (5) \\
\hline Koeleria macrantha & . & . & . & . & (I) & 0 & 0 & 0 & 0 & (6) \\
\hline Agrostis stolonifera & . & . & . & . & (I) & 0 & 0 & 0 & 0 & (7) \\
\hline Festuca ovina & . & . & . & . & (I) & 0 & 0 & 0 & 0 & (6) \\
\hline Prunella vulgaris & . & . & . & . & (III) & 0 & 0 & 0 & 0 & (4) \\
\hline Leontodon autumnalis & . & . & . & . & (III) & 0 & 0 & 0 & 0 & (5) \\
\hline Luzula campestris & V & V & IV & V & (III) & 1 & 1 & 1 & 1 & (6) \\
\hline Danthonia decumbens & . & . & . & . & (I) & 0 & 0 & 0 & 0 & (5) \\
\hline Potentilla erecta & . & . & . & . & (I) & 0 & 0 & 0 & 0 & (4) \\
\hline Succisa pratensis & . & . & . & . & (I) & 0 & 0 & 0 & 0 & (5) \\
\hline Pimpinella saxifraga & . & $\mathrm{V}$ & V & III & (I) & 0 & 1 & 2 & 1 & (4) \\
\hline Stachys officinalis & . & . & . & . & (I) & 0 & 0 & 0 & 0 & (5) \\
\hline Carex caryophyllea & . & . & . & . & (I) & 0 & 0 & 0 & 0 & (4) \\
\hline Conopodium majus & $\mathbf{V}$ & V & IV & $\mathbf{V}$ & (I) & 3 & 3 & 1 & 1 & (5) \\
\hline Ranunculus acris & III & V & $\mathbf{V}$ & $\mathbf{V}$ & (III) & 1 & 3 & 3 & 3 & (4) \\
\hline Rumex acetosella & $\mathrm{V}$ & V & V & V & (III) & 4 & 5 & 4 & 2 & (4) \\
\hline Hypochoeris radicata & . & . & . & . & (III) & 0 & 0 & 0 & 0 & (5) \\
\hline Ranunculus bulbosus & . & . & . & III & (III) & 0 & 0 & 0 & 1 & (7) \\
\hline Taraxacum seedlings & . & . & . & . & (III) & 0 & 0 & 0 & 0 & (4) \\
\hline Brachythecium rutabulum & . & . & . & . & (III) & 0 & 0 & 0 & 0 & (6) \\
\hline Cerastium fontanum & . & V & V & . & (II) & 0 & 2 & 2 & 0 & (3) \\
\hline
\end{tabular}


Constancy values

IUB ILB ILC 1LD MG5
Maximum Domin score IUB ILB 1LC 1LD MG5

\begin{tabular}{|c|c|c|c|c|c|c|c|c|c|c|}
\hline Leontodon hispidus & . & . & IV & $\mathrm{V}$ & (II) & 0 & 0 & 3 & 5 & (6) \\
\hline Rhinanthus minor & . & . & . & $\theta^{\circ}$ & (II) & 0 & 0 & 0 & 0 & (5) \\
\hline Briza media & . & . & . & III & (II) & 0 & 0 & 0 & 1 & (6) \\
\hline Heracleum sphondylium & . & . & . & . & (II) & 0 & 0 & 0 & 0 & (5) \\
\hline Trifolium dubium & . & . & . & . & (II) & 0 & 0 & 0 & 0 & $(8)$ \\
\hline Primula veris & . & . & . & . & (II) & 0 & 0 & 0 & 0 & (4) \\
\hline Arrhenatherum elatius & V & $\mathrm{V}$ & $\mathrm{V}$ & V & (II) & 1 & 3 & 4 & 2 & (7) \\
\hline Cirsium arvense & . & . & . & . & (II) & 0 & 0 & 0 & 0 & (4) \\
\hline Eurhynchium praelongum & . & . & . & . & (II) & 0 & 0 & 0 & 0 & (5) \\
\hline Rhytidiadelphus squarrosus & . & . & . & . & (II) & 0 & 0 & 0 & 0 & (7) \\
\hline Poa pratensis & V & $\mathrm{V}$ & $\mathrm{V}$ & $\mathrm{V}$ & (II) & 2 & 3 & 3 & 3 & (6) \\
\hline Poa trivialis & . & . & $\mathrm{V}$ & . & (II) & 0 & 0 & 2 & 0 & (8) \\
\hline Veronica chamaedrys & . & . & II & . & (II) & 0 & 0 & 1 & 0 & (4) \\
\hline Alopecurus pratensis & V & V & V & III & (I) & 3 & 4 & 3 & 2 & (6) \\
\hline Cardamine pratensis & . & . & . & . & (I) & 0 & 0 & 0 & 0 & (3) \\
\hline Vicia cracca & . & . & . & . & (I) & 0 & 0 & 0 & 0 & (4) \\
\hline Bromus hordeaceus & . & III & II & . & (I) & 0 & 1 & 1 & 0 & (6) \\
\hline Phleum pratense pratense & . & . & . & . & (I) & 0 & 0 & 0 & 0 & (6) \\
\hline Juncus effusus & . & . & . & . & (I) & 0 & 0 & 0 & 0 & (3) \\
\hline Phleum pratense bertolonii & . & . & . & . & (I) & 0 & 0 & 0 & 0 & (3) \\
\hline Calliergon cuspidatum & . & . & . & . & (I) & 0 & 0 & 0 & 0 & $(5)$ \\
\hline Ranunculus repens & . & . & . & . & (I) & 0 & 0 & 0 & 0 & (7) \\
\hline Pseudoscleropodium purum & . & . & . & . & (I) & 0 & 0 & 0 & 0 & (5) \\
\hline Ophioglossum vulgatum & . & . & . & . & (I) & 0 & 0 & 0 & 0 & (5) \\
\hline Silaum silaus & . & . & . & . & (I) & 0 & 0 & 0 & 0 & (5) \\
\hline Agrimonia eupatoria & . & . & . & . & (I) & 0 & 0 & 0 & 0 & (5) \\
\hline Avenula pubescens & V & V & V & V & (I) & 1 & 4 & 7 & 5 & (5) \\
\hline Plantago media & . & . & . & . & (I) & 0 & 0 & 0 & 0 & (4) \\
\hline Alchemilla glabra & . & . & . & . & (I) & 0 & 0 & 0 & 0 & (3) \\
\hline Alchemilla filicaulis & . & . & . & . & (I) & 0 & 0 & 0 & 0 & (3) \\
\hline Alchemilla xanthochlora & . & . & . & . & (I) & 0 & 0 & 0 & 0 & (3) \\
\hline Carex paniculata & . & . & . & $\cdot$ & (I) & 0 & 0 & 0 & 0 & (4) \\
\hline Colchicum autumnale & . & . & . & $\cdot$ & (I) & 0 & 0 & 0 & 0 & (4) \\
\hline Crepis capillaris & . & . & . & V & (I) & 0 & 0 & 0 & 1 & (5) \\
\hline Festuca arundinacea & . & . & . & . & (I) & 0 & 0 & 0 & 0 & (5) \\
\hline Potentilla reptans & . & . & II & . & (I) & 0 & 0 & 1 & 0 & (6) \\
\hline Senecio jacobaea & . & . & II & . & (I) & 0 & 0 & 1 & 0 & (4) \\
\hline Filipendula ulmaria & . & . & . & . & (I) & 0 & 0 & 0 & 0 & (5) \\
\hline Juncus articulatus & . & . & . & . & (I) & 0 & 0 & 0 & 0 & (5) \\
\hline
\end{tabular}

Species found in the test data at a constancy of II or more but which do not appear in MG5 diagnosis:

Plot 1L(B) Stellaria graminea V

Plot 1L(C) Ajuga reptans II, Taraxacum sp. V, Tragopogon pratense II

Plot 1L(D) Taraxacum sect. V. 
Acknowledgements: This work was supported by a research grant from the Natural Environment Research Council. J.Potts acknowledges the support of the Leverhulme Trust. We thank John Rodwell for comments on the manuscript.

\section{REFERENCES}

BRenChley W.E. \& WaRINGTON K. (1958): The Park Grass Plots at Rothamsted 1856-1949. - Rothamsted Experimental Station, Harpenden.

GouldiNG K.W.T. \& POULTON P.R. (1985): Acid deposition at Rothamsted, Saxmundham and Woburn, 1969-83. - Soil Use Manag. 1(2): 6-8.

JOHNSTON A.E., GOULDING K.W.T. \& POULTON P.R. (1986): Soil acidification during more than 100 years under permanent grassland and woodland at Rothamsted. - Soil Use Manag. 2(1): 3-10.

KERSHAW K.A. (1973): Quantitative and dynamic plant ecology. 2nd Edition. - Edward Arnold, London.

LAWES J.B. \& GILBERT J.H. (1858): Report of experiments with different manures on permanent meadow land. - J. Roy. Agric. Soc. England, 1st series 19: 552-573.

PIGOTT C.D. (1982): The experimental study of vegetation. - New Phytol. 90: 389-404.

RICH T.C.G., COOPER E.A., RODWELL J. S. \& MALLOCH A.J.C. (1993): The impact of climate change and air pollution on British calcicolous ecosystems. - Department of the Environment Project Report, London.

ROBERTS H.A. (1986): Persistence of some grass species in cultivated soil. - Grass Forage Sci. 41: 273-276.

RODWELL J.S. [ed.] (1991): British plant communities. Vol 1. Woodlands and scrub. - Cambridge University Press, Cambridge.

RODWELL J.S. [ed.] (1992a): British plant communities. Vol 2. Mires and heaths. - Cambridge University Press, Cambridge.

RODWELL J.S. [ed.] (1992b): British plant communities. Vol 3. Grasslands and mountain communities. Cambridge University Press, Cambridge.

THOMPSON K. \& GRIME J.P. (1983): A comparative study of germination responses to diurnally-fluctuating temperatures. - J. Appl. Ecol. 20: 141-156.

THURSTON J.M. (1969): The effect of liming and fertilizers on the botanical composition of the permanent grassland, and on the yield of hay. - Symposium of the British Ecological Society.

Thurston J. M., Williams E.D. \& JohNSTON A.E. (1976): Modern developments in an experiment on permanent grassland started in 1856: effects of fertilizers and lime on botanical composition and crop and soil analyses. - Ann. agron. 27: 1043-1082.

WILliams E.D. (1978): Botanical composition of the Park Grass Plots at Rothamsted. - Rothamsted Experimental Station, Harpenden.

Received 7 December 1993, accepted 9 March 1994 